\title{
Analysis of the Use of Videoconferencing in the Learning Process During the Pandemic at a University in Lima
}

\author{
Angie Del Rio-Chillcce ${ }^{1}$, Luis Jara-Monge ${ }^{2}$, Laberiano Andrade-Arenas ${ }^{3}$ \\ Faculty of Science and Engineering \\ University of Sciences and Humanities \\ Lima, Perú
}

\begin{abstract}
Due to the health emergency situation, which forced universities to stop using their centers as a means of teaching, many of them opted for virtual education. Affecting the learning process of students, which has predisposed many of them to become familiar with this new learning process, making the use of virtual platforms more common. Many educational centers have come to rely on digital tools such as: Discord, Google Meet, Microsoft Team, Skype and Zoom. The objective of the research is to report on the impact of student learning through the use of the aforementioned videoconferencing tools. Surveys were conducted with teachers and students who stated that $66 \%$ were not affected in their educational development. Most of them became familiar with the platforms; however, less than $24 \%$ qualified that their academic performance has improved, some teachers still have difficulties at a psychological level due to this new teaching modality. In conclusion, teachers and students agree that these tools are a great help for virtual classes.
\end{abstract}

Keywords-Digital tools; health emergency; universities; video conferencing; virtual education

\section{INTRODUCTION}

Globally, due to the new pandemic SARS-CoV-2 or known as COVID-19, the use of different softwares for student education is increasing. Less than a decade ago, videoconferencing was only used to avoid unnecessary expenses on business trips, thus reducing savings on lodging and time.

There was an abrupt change with the arrival of this new virus. This has led to a growing need for all students (from kindergarten to university level) to establish and become familiar with this new teaching and learning process, making the frequent use of these platforms more common.

Online class imbalance learning is a new problem that is happening in the real world [1]. In Indonesia, there are two problems that inhibit its education system, namely, transportation and distance. As a first solution, they applied the use of information and communication technologies (ICT). To reach a large mass of students, they created the Virtual Class Box (VCB) 5.0 device to support digital distance learning between teachers and students [2].

On the other hand, China rushed and experimented for a two-month trial period by forcing its universities to work remotely [3], obtaining as a result of their ICT, acceptable academic performance. However, he also stated that online platforms are not explicitly for student purposes.
Latin American countries such as Uruguay, created a digital program designed exclusively for the quality of teaching and learning in students due to the shortage of teachers [4].

One of the ways of interactivity is the so-called Discord application [5], normally used for video games. In their latest updates they added the trend of video calls, based on this, the student-teacher activities improved, consolidating the educational synergy.

In this day and age, conventional education is having gaps when it comes to teaching. Because, due to factors beyond their control, the immobilization of people decreed by many governments worldwide has left them alone at home, unable to go out, much less to places where there is a conglomeration of people. Education at any level has been affected in the delivery of classes [6].

Currently, the need for Peruvian students has increased by $80 \%$ the use of online classes. Because virtually the entire $100 \%$ of their houses of study will be disabled in person to prevent the spread of the virus from March 16, 2020 to date. By carrying out virtual meeting platforms such as Zoom or Google meet.

Today, they are the most innovative and adaptable means of telecommunication to our new national lifestyle. Since, it allows to establish a more real and visual connection between teachers and students. Helping also not to delay education. A study in 2019 [7], demonstrates that online learning helps university students improve their academic performance.

As it is in one of the Peruvian professional study houses, Universidad de Ciencias y Humanidades, in which the pandemic forced all its teachers to use videoconferencing without having previous knowledge of these, making a sudden change in the teaching methodology, since the virtual meeting platforms such as zoom and google meet had a time limit. Therefore, by having unique videoconferencing platforms, students will be able to receive instructions as if they were in person, and maintain the synergy of real-time intercommunication. However, these habits are not well received by some courses that require mandatory explanations by the physical presence of a teacher; discarding the disadvantages that some may have due to the quality of the network in their homes.

By carrying out this work we will make a research contribution and, above all, we will see that each person has a different learning pace, which leads us to question, with the 
excellent quality of the platforms, are videoconferences really effective for university teaching and learning?

The objective of this article is to know the impact of different videoconferencing tools that have been used in the teaching and learning process at a University in northern Lima in times of pandemic.

The structure of the article is as follows: Section II, Literature Review, the antecedents will be explained; in Section III, Methodology, the steps to be followed will be detailed; in Section IV Results are discussed; in Section V, Discussions and in Section VI Conclusions and Future Work are discussed.

\section{LITERATURE REVIEW}

Currently, in times of pandemic, teaching is at a distance where the use of different means of videoconferencing is relevant in education. Since, it has a very significant role in the learning experience of the students [8].

The author [9], indicates that ICT has contributed to the new educational reforms. Google meet was mostly used by students in work meetings as opposed to teachers who preferred to zoom in on class meetings.

The use of the Zoom Videoconferencing platform helps both teachers and students in their work, teaching and learning, which allows both parties to interact and learn about the benefits of the platform, in addition to creating a socially positive learning environment [10]. The author [9], [10] coincide in their methodologies, since both apply a quantitative approach, having as statistical results, where a good percentage of Zoom videoconferences are accepted by students and teachers.

On the other hand, the author [11] mentions in the results of his studies that students do not have problems related to virtual education using videoconferencing platforms, however, there is a latent concern about issues related to the laboratory since, in it, they needed instruments that only the University could provide and that the vast majority of students do not have the possibility of acquiring.

In similar instances, a university student group, in their article [12], emphasized that it is not only in the professional field that institutions use videoconferencing for teaching.

In a study of e-learning, the modern form of online learning, the following benefits were found [13], such as costeffectiveness, learning flexibility and, above all, the independent part.

In an investigation [14], explains that students have learning effectiveness during their online classes using Discord, as it allows access to requested activities and availability. However, what is detrimental to its reinforcement is the low quality of its network speed and the self-conscious behavior on the part of the students when they do not contribute opinions by activating their microphones.

Students in Indonesia, however, refuted that answer [15], he mentioned that when his students use videoconferencing tools in their classes, the behavior of the students is different, assuring that many of them have managed to overcome the shyness of speech, in which, virtually, they have more courage to contribute their opinions.

\section{Methodology}

The following will describe the most influential points of Videoconferencing platforms that contribute to virtual education, such as: Discord, Google Meet, Microsoft Teams, Skype, Zoom.

\section{A. Survey}

In this work 2 surveys were applied to: 25 university students and 10 teachers of the University of Sciences and Humanities of the career of Systems and Computer Engineering, using the Google Form tool to carry out these surveys. These surveys will help us to collect data from both students and teachers.

-Link to the survey for teachers:

docs.google.com/forms/d/1T6ZF X6Forz4

$U_{Q} h L K x H A I L y A 1 I T Y Q 698 i 0 u q 8 o A Y 0 V c$

Table I, lists the questions on the form for teachers.

TABLE I. TEACHER SURVEy TABLE

\begin{tabular}{ll}
\hline $\mathrm{N}^{\circ}$ & Teacher Survey \\
\hline \hline 1 & $\begin{array}{l}\text { ¿At what level do you consider you are psychologically and pedagog- } \\
\text { ically qualified to work with virtual videoconferencing tools? }\end{array}$ \\
\hline 2 & $\begin{array}{l}\text { ¿How many hours have you increased your workload to develop your } \\
\text { online classes? }\end{array}$ \\
\hline 3 & $\begin{array}{l}\text { From your perspective, do you feel that stress has built up during the } \\
\text { new teaching methodology? }\end{array}$ \\
\hline 5 & $\begin{array}{l}\text { ¿Do you think you need to improve your digital skills to face the new } \\
\text { teaching and learning processes in virtual environments? }\end{array}$ \\
\hline 6 & $\begin{array}{l}\text { Nowadays, the use of different videoconferencing platforms has diver- } \\
\text { sified. On a scale of } 1 \text { to } 5, \text { indicate your knowledge of each of them, } \\
\text { where } 1 \text { is none and } 5 \text { is total. }\end{array}$ \\
\hline 7 & $\begin{array}{l}\text { Rate the following tools, indicating the level of use in your online } \\
\text { classes. }\end{array}$ \\
\hline 8 & $\begin{array}{l}\text { From your point of view, do you feel comfortable with the new } \\
\text { teaching modality? }\end{array}$ \\
\hline
\end{tabular}

-Link to student survey:

docs.google.com/forms/d/1o7cqxYVTB $B_{z} J$ EoRSS - 8W9LnyAIco5ll8IgiQQ2xJU

In Table II, we will mention the questions in the survey focused on students.

\section{B. Zoom}

Zoom is a tool used for synchronous online teaching, which allows you to work efficiently. It includes several functions such as: annotation tools, polls, meeting rooms and video and screen sharing. These functions facilitate learning [16].Below in Table III, the most important tools of the Zoom platform will be detailed.

It offers innovative learning opportunities and tools, integrating video conferencing and teacher-student communication. 
TABLE II. StUdent SURVEY QUESTIONS

\begin{tabular}{ll}
\hline $\mathrm{N}^{\circ}$ & Student Survey \\
\hline \hline 1 & $\begin{array}{l}\text { ¿Do you consider that your level of learning has increased in the new } \\
\text { virtual learning environment? }\end{array}$ \\
\hline 2 & $\begin{array}{l}\text { ¿Does teaching teachers via videoconferencing help you learn? } \\
\text { according to the aforementioned. Give a brief explanation of your }\end{array}$ \\
\hline 3 & $\begin{array}{l}\text { ¿Do you think you need to strengthen your digital skills to adapt to } \\
\text { new learning processes in virtual environments? }\end{array}$ \\
\hline 5 & $\begin{array}{l}\text { Currently, the use of the different Videoconferencing platforms has } \\
\text { diversified. On a scale of 1 to 5, mention the knowledge of each of } \\
\text { them, where 1 is nil and } 5 \text { is total. }\end{array}$ \\
\hline 6 & $\begin{array}{l}\text { Please rate the following tools, indicating the level of use in your } \\
\text { online classes }\end{array}$ \\
\hline 8 & $\begin{array}{l}\text { ¿From your point of view, do you feel comfortable with the new } \\
\text { learning modality? }\end{array}$ \\
\hline 9 & $\begin{array}{l}\text { ¿How often do you have trouble concentrating during your online } \\
\text { classes? }\end{array}$ \\
\hline
\end{tabular}

TABLE III. MAIN ZoOM TOOLS

\begin{tabular}{ll}
\hline \multicolumn{1}{c}{ TOOLS } & USAGE \\
\hline \hline Start a meeting & Create a videoconference. \\
\hline Schedule a meeting & $\begin{array}{l}\text { Allows you to schedule a specific day and time } \\
\text { for the meeting. }\end{array}$ \\
\hline Use of the calendar & $\begin{array}{l}\text { Gives the option to use Google calendar, to receive } \\
\text { notifications of meetings already scheduled. }\end{array}$ \\
\hline Screen sharing & $\begin{array}{l}\text { Allows all participants to have the option to } \\
\text { choose what to share with other meeting partic- } \\
\text { ipants }\end{array}$ \\
\hline Screen Recorder & $\begin{array}{l}\text { It is useful to replay the meeting as many times } \\
\text { as you want, it is very helpful to take notes and } \\
\text { remember some details. }\end{array}$ \\
\hline Virtual whiteboard & $\begin{array}{l}\text { Allows you to draw, write or carry out explana- } \\
\text { tions in an easier way. }\end{array}$ \\
\hline Chat & $\begin{array}{l}\text { Participants have the option to interact both di- } \\
\text { rectly and privately. }\end{array}$ \\
\hline Live Broadcasting & $\begin{array}{l}\text { It is used to make live broadcasts using applica- } \\
\text { tions such as Facebook or Youtube. }\end{array}$ \\
\hline User management & $\begin{array}{l}\text { You have the option to enable and disable the } \\
\text { audio and video of the participants, as well as } \\
\text { manage which user enters the meeting. }\end{array}$ \\
\hline
\end{tabular}

In Table IV, some advantages and disadvantages of the platform are mentioned.

TABLE IV. TABle Advantages and Disadvantages of Zoom

\begin{tabular}{ll}
\hline Advantages & Disadvantages \\
\hline \hline $\begin{array}{l}\text { The pc version and mobile application } \\
\text { has a relatively easy, comfortable and } \\
\text { intuitive interface. }\end{array}$ & $\begin{array}{l}\text { Despite being an easy to use tool, it can } \\
\text { be confusing for some people who are } \\
\text { not adapted to this new technology. }\end{array}$ \\
\hline It has a free version & $\begin{array}{l}\text { It has a } 40 \text { minutes limit for the free } \\
\text { version. }\end{array}$ \\
\hline Allows screen sharing in real time & $\begin{array}{l}\text { As it is a synchronous application the } \\
\text { use of internet or a stable connection is } \\
\text { important. }\end{array}$ \\
\hline $\begin{array}{l}\text { No need to be registered to join a meet- } \\
\text { ing, nor download the application }\end{array}$ & $\begin{array}{l}\text { It collects data and emails from all con- } \\
\text { nected devices exposing the user. }\end{array}$ \\
\hline $\begin{array}{l}\text { A permanent ID will be assigned to the } \\
\text { user }\end{array}$ & $\begin{array}{l}\text { It is no necessary to download and in- } \\
\text { stall the application to use it. }\end{array}$ \\
\hline
\end{tabular}

In Fig. 1, the main and basic Zoom tools are shown.

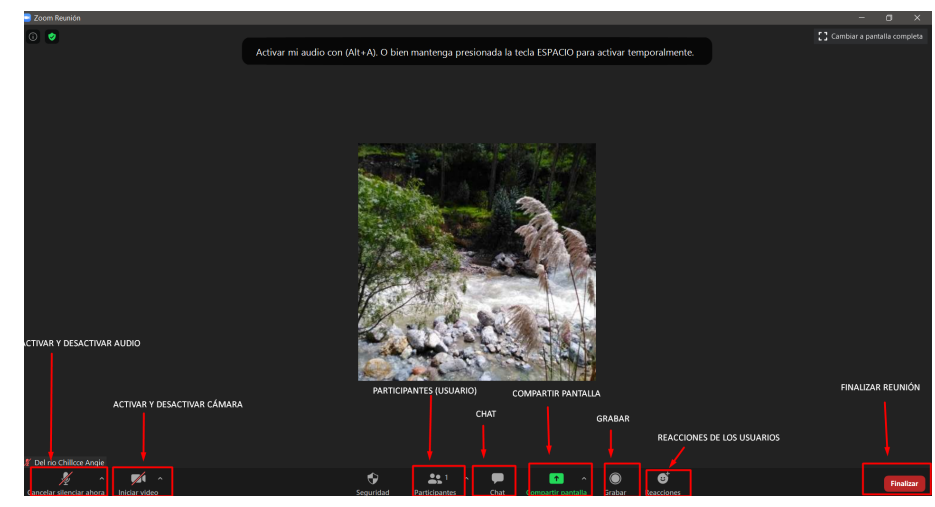

Fig. 1. Zoom Interface.

\section{Google Meet}

Google Meet is a relatively recent application [17], was launched in April 2020 to all users, free of charge. It was previously known as Hangouts. It is mainly focused on companies and educational centers.

Below in Table $\mathrm{V}$, the most important tools of the Meet platform will be detailed.

TABLE V. Main MeEt tools

\begin{tabular}{ll}
\hline TOOL & USE \\
\hline \hline Create a video call & $\begin{array}{l}\text { Allows you to create the video call, by logging in } \\
\text { with your Google account. }\end{array}$ \\
\hline $\begin{array}{l}\text { Invite other users to join a } \\
\text { meeting }\end{array}$ & $\begin{array}{l}\text { Gives you a meeting link or code that you can } \\
\text { send to other users. }\end{array}$ \\
\hline Screen sharing & $\begin{array}{l}\text { Allows you to show your screen or the window of } \\
\text { an application. }\end{array}$ \\
\hline Screen Recording & $\begin{array}{l}\text { Allows you to record the sessions so that the } \\
\text { student has all the information at hand. }\end{array}$ \\
\hline Chat & Users can interact by sharing files and views. \\
\hline Controls for hosts & The host can mute, set or delete a user. \\
\hline
\end{tabular}

In Table VI, some advantages and disadvantages of the Meet platform are mentioned.

\section{TABLE VI. Advantages and Disadvantages of Meet}

\begin{tabular}{ll}
\hline Advantages & Disadvantages \\
\hline \hline $\begin{array}{l}\text { Allows you to create meetings with } \\
\text { more than } 200 \text { participants }\end{array}$ & 60 minutes limit for the free version. \\
\hline $\begin{array}{l}\text { Facilitates real-time captioning during } \\
\text { conversation }\end{array}$ & $\begin{array}{l}\text { Has few mechanisms to control user } \\
\text { audio. }\end{array}$ \\
\hline It has a simple and deductible interface & $\begin{array}{l}\text { Each participant must be registered or } \\
\text { have a Google account. }\end{array}$ \\
\hline $\begin{array}{l}\text { The security of the videoconference is } \\
\text { guaranteed due to the encryption of the } \\
\text { transmissions }\end{array}$ & $\begin{array}{l}\text { it is a synchronous application, this } \\
\text { means that the internet connection is } \\
\text { indispensable. }\end{array}$ \\
\hline
\end{tabular}

Google Meet is closely connected to Google Suite, this makes it possible to add meetings through Event Calender.

In Fig. 2, the main Meet tools are shown. 


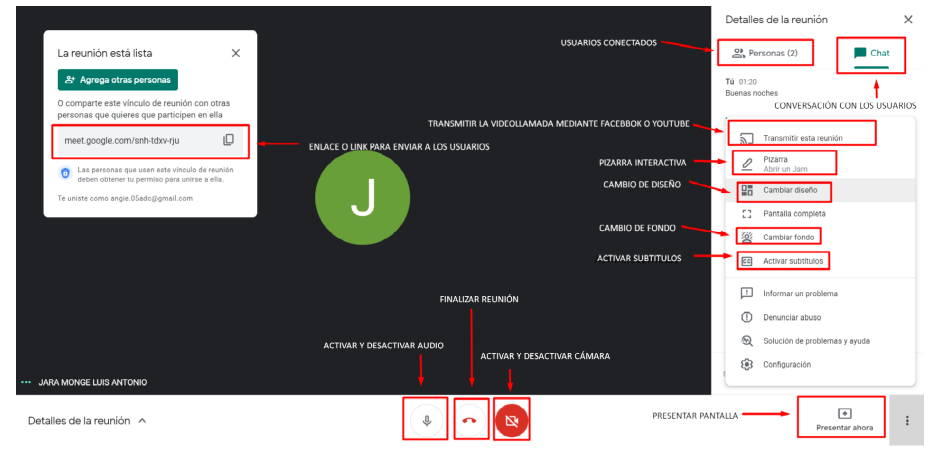

Fig. 2. Meet Interface.

Like the other virtual meeting platforms, this one offers its services at zero prices, i.e. free of charge, so that people can meet at a distance. Despite being an offshoot of Microsoft's own [18]. Table VII shows the features that Skype has.

TABLE VII. SKyPE APPLiCATion FEATURES

\begin{tabular}{ll}
\hline HERRAMIENTA & USO \\
\hline \hline Speed per calls & 24kbps / 128kbps. \\
\hline Courier writing & Unlimited for ongoing call. \\
\hline Call recording & If in case the guests want to see the show again. \\
\hline Shared screen & $\begin{array}{l}\text { It has the ability to transmit live presentations from } \\
\text { the phone or computer. }\end{array}$ \\
\hline Multi platform & $\begin{array}{l}\text { phone, pc, laptops, tablets, has accessibility to } \\
\text { Skype. }\end{array}$ \\
\hline
\end{tabular}

We continue with Table VIII, the advantages and disadvantages of this virtual meeting platform will be detailed.

TABLE VIII. Advantages and Disadvantages of Skype

\begin{tabular}{ll}
\hline Advantages & Disadvantages \\
\hline \hline $\begin{array}{l}\text { Skype has accessibility for } \\
\text { the different Operating Sys- } \\
\text { tems such as: Windows, Mac, }\end{array}$ & $\begin{array}{l}\text { It is not used mainly for academic meetings, both } \\
\text { university and school. }\end{array}$ \\
Linux, Android, iOS. & \\
\hline $\begin{array}{l}\text { Advanced Encryption Stan- } \\
\text { dard Security. }\end{array}$ & $\begin{array}{l}\text { Sometimes during video call, video and audio } \\
\text { quality tends to drop, which is annoying for users. }\end{array}$ \\
\hline $\begin{array}{l}\text { It has the capacity of 50 peo- } \\
\text { ple connected in real time. }\end{array}$ & $\begin{array}{l}\text { If the time limit exceeds, the video transmission } \\
\text { is cut off, however, the call continues as audio. }\end{array}$ \\
\hline
\end{tabular}

In the Fig. 3, the tools of said platform are indicated by arrows.

\section{E. Microsoft Teams}

This virtual meeting platform is also used by hundreds of students nationwide, launched since 2017 becoming better known by the education sector since the year 2019, as well as providing a good integrated teaching and learning space [19].

Next, it is detailed in Table IX, the characteristics that the platform carries within a videoconference on-line.

To achieve a distinction between the aforementioned platforms, it will be detailed in Table $\mathrm{X}$, the advantages and

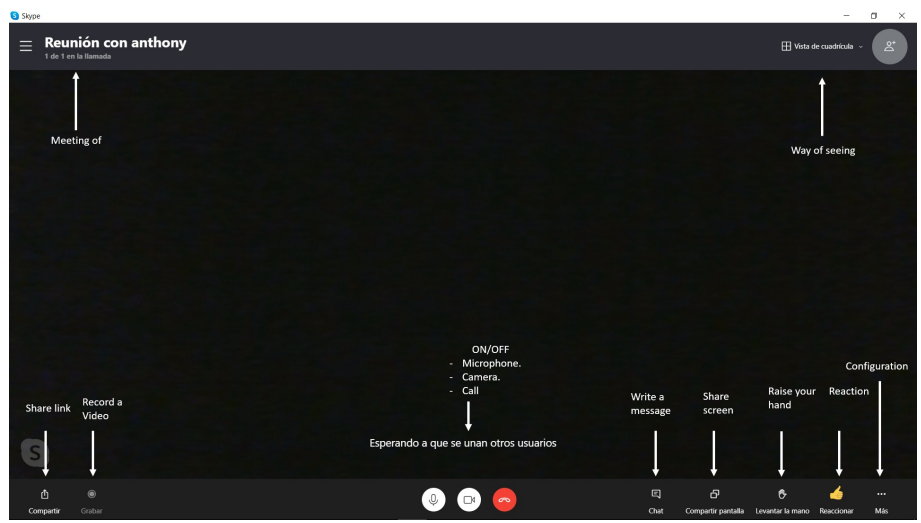

Fig. 3. Skype Platform.

TABLE IX. App Features Microsoft Teams

\begin{tabular}{ll}
\hline TOOL & USE \\
\hline \hline Messenger service & $\begin{array}{l}\text { Ability to communicate personally with one of the } \\
\text { members. }\end{array}$ \\
\hline Time limit & $\begin{array}{l}\text { The platform can be used between users for } 24 \\
\text { hours at a time. }\end{array}$ \\
\hline Time & Shows the time spent inside the room.. \\
\hline Setting & $\begin{array}{l}\text { Shows other options available to the application, } \\
\text { such as: audio distribution. }\end{array}$ \\
\hline Leave & $\begin{array}{l}\text { By pressing that option, the member can exit the } \\
\text { live session. }\end{array}$ \\
\hline Reactions & $\begin{array}{l}\text { Interaction of members, such as: raising your hand } \\
\text { to give your opinion, then the host will respond to } \\
\text { your request. }\end{array}$ \\
\hline
\end{tabular}

disadvantages of the Microsoft Teams video conferencing platform.

TABLE X. Advantages and Dis advantages of Microsoft Teams

\begin{tabular}{ll}
\hline Advantages & Disadvantages \\
\hline \hline $\begin{array}{l}\text { PKI security Protect data used } \\
\text { to encrypt transport layer con- } \\
\text { nections. }\end{array}$ & It has a paid version for the full use of its services. \\
\hline $\begin{array}{l}\text { Has resources at the time of } \\
\text { live meetings }\end{array}$ & $\begin{array}{l}\text { It does not allow more than } 300 \text { users working } \\
\text { simultaneously. }\end{array}$ \\
\hline $\begin{array}{l}\text { It has a free plan, however, it } \\
\text { restricts some tools }\end{array}$ & $\begin{array}{l}\text { A large percentage of users do not feel con- } \\
\text { formism with the tools, that is, difficult adaptabil- } \\
\text { ity without prior training. }\end{array}$ \\
\hline $\begin{array}{l}\text { Your files are stored in the } \\
\text { cloud. (Drive) }\end{array}$ & Requires the mandatory use of the internet. \\
\hline
\end{tabular}

In Fig. 4, each of the parts that Microsoft Teams has during a live meeting are noted.

F. Discord

The Discord platform is a means of creating a quality remote environment during emergency training. [20]. It is used 


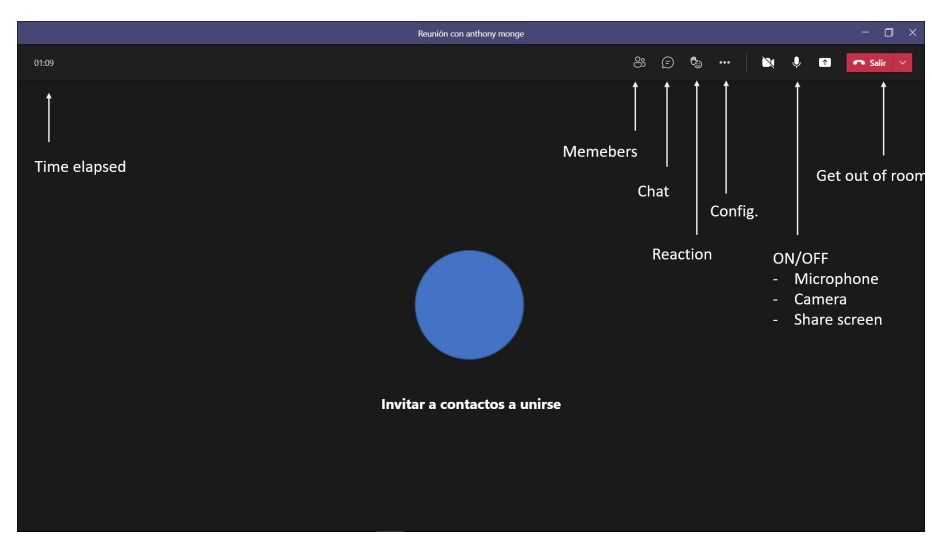

Fig. 4. Microsoft Teams Platform.

to convert a traditional class to a virtual class, a monotonous listening class into an engaging listening class. In Table XI, we will proceed to list some of its tools.

TABLE XI. DisCORD APP FEATURES

\begin{tabular}{ll}
\hline TOOL & USE \\
\hline \hline Add contact & Be able to add a user to make the video call. \\
\hline Create video call & Lets create the video call. \\
\hline Share screen & $\begin{array}{l}\text { Allows video call participants to choose what to } \\
\text { share. }\end{array}$ \\
\hline Chat & It serves to have a more direct communication. \\
\hline
\end{tabular}

The following is detailed in Table XII, some advantages and relevant disadvantages of the videoconferencing platform Discord.

TABLE XII. Advantages And Disadvantages of THE Discord APPLICATION

\begin{tabular}{ll}
\hline Advantages & Disadvantages \\
\hline \hline $\begin{array}{l}\text { Due to the optimized perfor- } \\
\text { mance, you can communicate } \\
\text { without losing call quality. }\end{array}$ & $\begin{array}{l}\text { After the launch of the paid version (Discord } \\
\text { Nitro, limited some features in version (Discord } \\
\text { Classic), and much more in its free version. }\end{array}$ \\
\hline The tool is cross-platform. & Requires previous training for its use. \\
\hline The platform is free. & $\begin{array}{l}\text { The video calling option is not optimized, so there } \\
\text { is a chance it will fail. }\end{array}$ \\
\hline $\begin{array}{l}\text { It is customizable for a better } \\
\text { user interface. }\end{array}$ & You do not have the option to record video calls. \\
\hline $\begin{array}{l}\text { Ability to provide class with } \\
\text { up to a maximum of } 50 \text { peo- } \\
\text { ple. }\end{array}$ & $\begin{array}{l}\text { Discord is not available for the Linux Operating } \\
\text { System. }\end{array}$ \\
\hline $\begin{array}{l}\text { Technical support available to } \\
\text { your users. }\end{array}$ & He had complaints from scammers. \\
\hline
\end{tabular}

In Fig. 5, the main interface of the Discord tool is shown, in addition to having a good educational and group environment, with a knowledge of the application there will be no deficiencies in its use. Multiple options are displayed within the interface that can be performed during a call in progress, either by transmission or just aural.

Through the comparisons made, it can be clearly concluded that the platforms have similar characteristics as: Time in which the class takes place, interaction option, screen sharing, writing internal messages to a user as well as in public. Except for Discord, for not having the option of video recording.

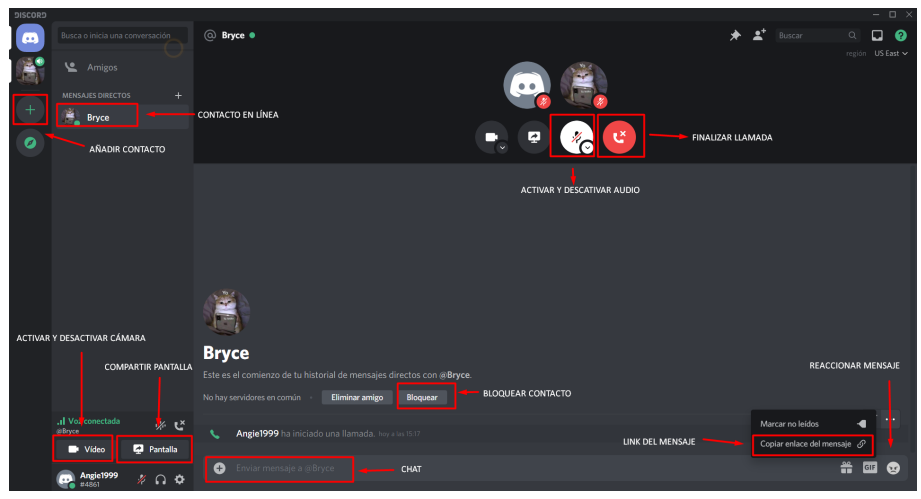

Fig. 5. Discord Conference.

Then, the videoconferences differ between them by one or another option of use, therefore, the student's learning and the teacher's teaching still remains to be analyzed, Therefore, the results of the survey carried out will be explained by means of graphics.

\section{RESUlTS}

A. Regarding the teachers surveyed:

- The $66.6 \%$ considers that he is highly trained physically and psychologically to work with videoconferencing tools, as well as the $33.4 \%$ consider it to be at an intermediate level. As shown in Fig. 6.

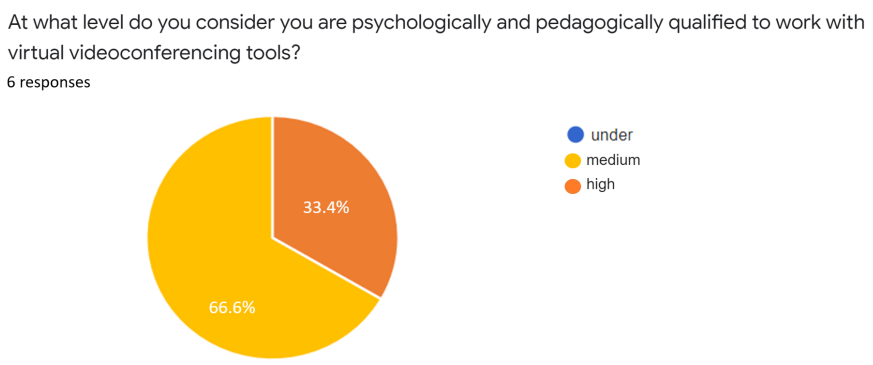

Fig. 6. Questions about Teacher Training.

- The $50 \%$ dedicates more than 3 hours (than normal) a day to develop his class, meanwhile the $33.3 \%$ dedicate 3 hours a day and $16.7 \%$ he claims he only spends 2 hours. As shown in Fig. 7.

- The $66.4 \%$ of teachers assess that they have accumulated a medium stress with the new teaching methodology, while the $16.8 \%$ considers that he accumulated high stress, in the same way the $16.8 \%$ accumulated low stress. As shown in Fig. 8.

- The $100 \%$ consider that you need to keep learning the new digital tools. As shown in Fig. 9. 
How many hours have you increased your workload to develop your online classes? 6 responses

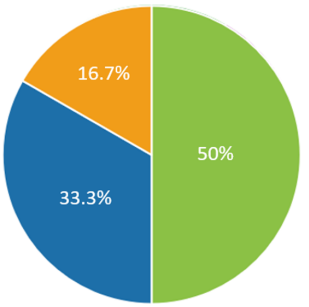

$$
\begin{aligned}
& 1 \text { hour } \\
& 2 \text { hours } \\
& 3 \text { hours } \\
& \text { more than } 3 \text { hours }
\end{aligned}
$$

Fig. 7. Ask about the Hours Dedicated to Developing the Class.

From your perspective, do you feel that stress has built up during the new teaching methodology? 6 responses

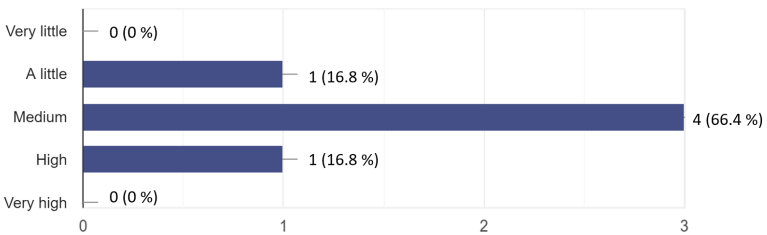

Fig. 8. Question about Accumulated Stress in Teachers.

Do you think you need to improve your digital skills to face the new teaching and learning processes in virtual environments?

6 responses

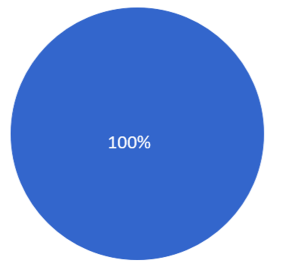

$$
\begin{aligned}
& \text { Yes } \\
& \text { No }
\end{aligned}
$$

Fig. 9. Ask about the New Digital Tools.

- $\quad$ The vast majority of teachers have a very high knowledge of the Zoom and Meet platforms, however they have a medium-low knowledge of the Skype, Microsoft Teams and Discord tools. As shown in Fig. 10 .

- Almost all teachers confirmed that they use the Zoom and Google Meet tools more frequently to teach their classes, as shown in Fig. 11.

- Only $16.7 \%$ considers that he feels very comfortable with this teaching modality; however, the $83.3 \%$ consider that you are comfortable with this mode of teaching. As shown in Fig. 12.
Nowadays, the use of different Videoconferencing platforms has diversified. On a scale of 1 to 5 , please indicate your knowledge of each of them, where 1 is null and 5 is total.

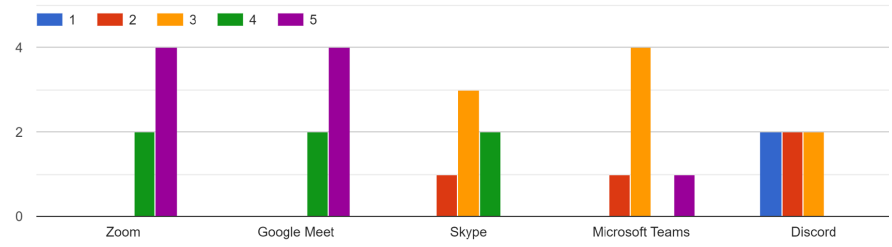

Fig. 10. Question about the Knowledge of Videoconferencing Tools.

Please rate the following tools, indicating the level of use for your online classes

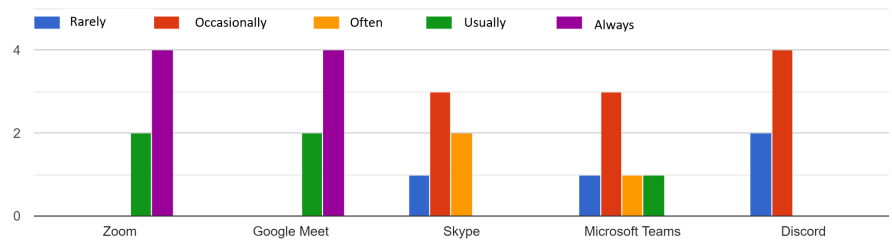

Fig. 11. Question about the use of Videoconferencing Tools.

From your point of view, do you feel comfortable with the new teaching modality? 6 responses

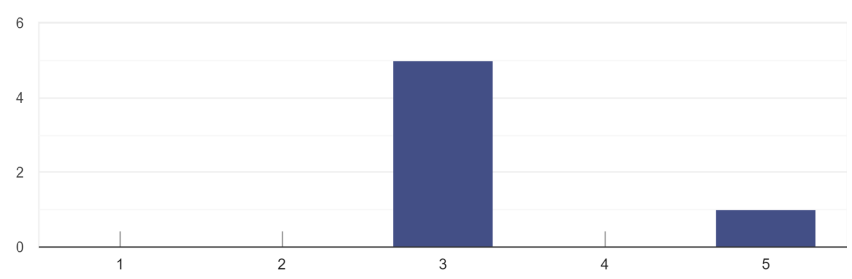

Fig. 12. Ask the Teacher about this New Teaching Method.

- An $83.4 \%$ of teachers consider that students' academic performance has remained on the sidelines and only $16.7 \%$ indicates that it has improved. As shown in Fig. 13.

B. Regarding the Surveyed Students:

- The $60 \%$ of students rate that their learning level has remained in a normal state, the $20 \%$ estimates that it has improved, and $8 \%$ qualifies that he has learned little; however, the $8 \%$ he considers that he has learned very little. As shown in Fig. 14. 
Based on the academic performance of your students, you consider: 6 responses

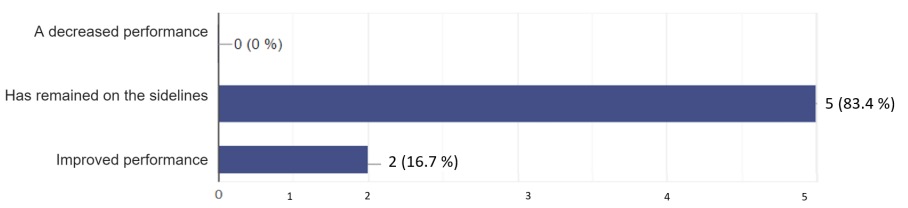

Fig. 13. Question about the Student's Academic Performance.

¿Do you consider that your level of learning has increased in the new virtual learning environment? 25 responses
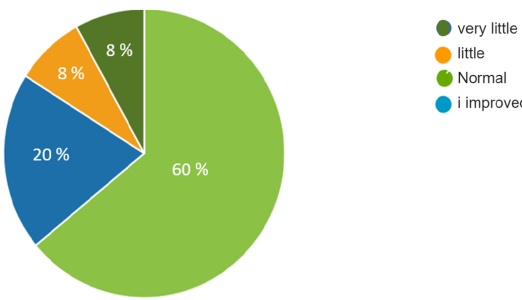

little

Norma

i improved

Fig. 14. Ask about the Student about their Level of Learning in New Virtual Learning Environment.

- The $68 \%$ of the surveyed students rate that they agree that video conferencing tools help them learn; however, the $32 \%$ considers that they do not agree. As shown in Fig. 15.

Is teaching teachers via video conferencing helping you learn? 25 responses

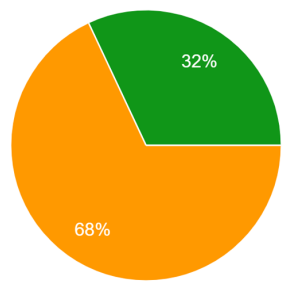

$$
\text { i agree }
$$$$
\text { idon't agree }
$$

Fig. 15. Ask about the Student about their Level of Learning via Video Conferencing.

- The $72 \%$ of respondents believe that they need to continue strengthening their digital knowledge, although, $28 \%$ consider not.

- The vast majority of students have a medium-high knowledge of the Zoom and Meet platforms, however, they have low-zero knowledge of the Skype, Microsoft Teams and Discord tools. As shown in Fig. 16.
Currently, the use of the various Videoconferencing platforms has diversified. On a scale from 1 to 5 , mention the knowledge of each one of them, where 1 is null and 5 is total.

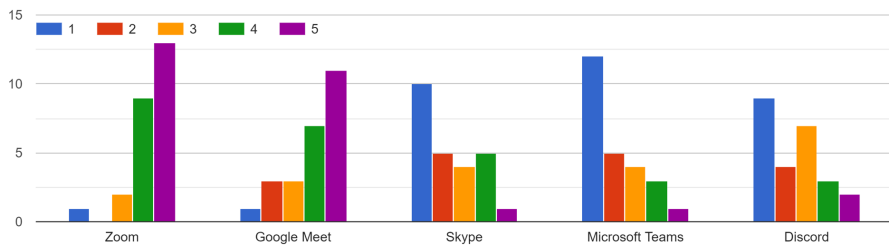

Fig. 16. Ask the Student about Knowledge of Videoconferencing Tools.

- Almost all students confirmed that they most frequently use the Zoom and Google Meet tools for their online classes. As shown in Fig. 17.

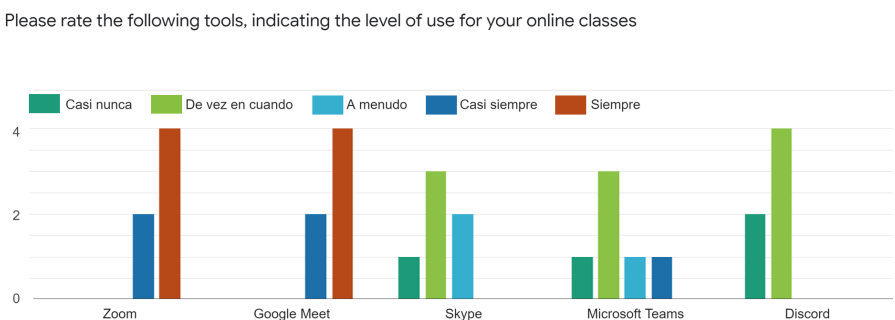

Fig. 17. Ask the Student about the use of Videoconferencing Tools.

- The $16 \%$ considers that he feels very comfortable regarding the new learning modality, a $20 \%$ rate that you feel comfortable, the $44 \%$ considers that it is normal, the $16 \%$ estimates that he feels uncomfortable, in the same way a $4 \% \mathrm{He}$ rated that he is not comfortable. As shown in Fig. 18.

¿From your point of view, are you comfortable with the new learning modality? 25 respuestas

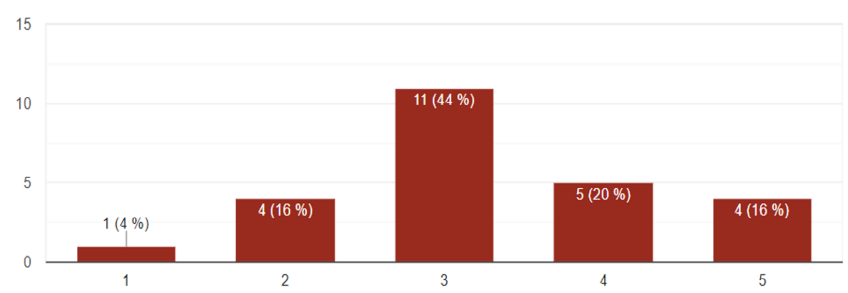

Fig. 18. Ask the Student about their Learning Comfort.

- The $52 \%$ indicated that he very seldom has concentration problems during classes, only on the $32 \%$ who has problems often, and the $16 \%$ indicates constantly has problems. As shown in Fig. 19.

- The $24 \%$ rated that their performance has improved considerably, the $60 \%$ considers that his performance has remained on the sidelines, and only the $16 \%$ indicates that its performance has decreased. As shown in Fig. 20. 
¿How often do you have trouble concentrating during your online classes? 25 respuestas

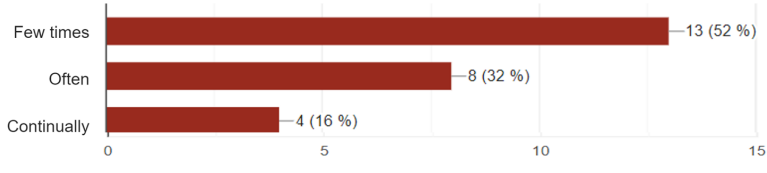

Fig. 19. Ask the Student about his Concentration During Class.

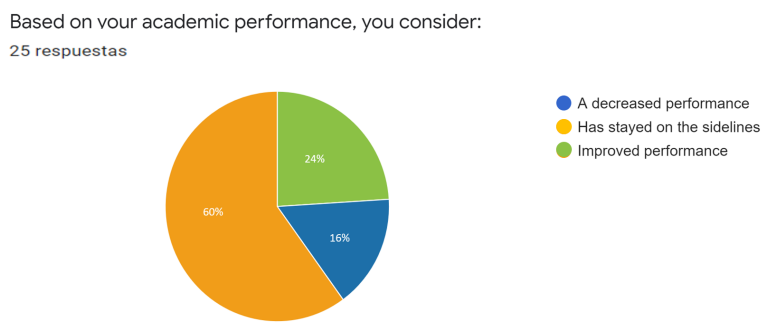

Fig. 20. Ask the Student about their Academic Performance.

\section{DISCUSSIONS}

During the points mentioned and analyzed for the use of these different virtual platforms, the financing aspect is essential due to various factors. Both by the student entity (University or college), as well as by the students for the usability of the conference applications [21].

According to the author [22], mentions that Zoom features are optimal for conducting video conferencing in an intuitive way. Another Study Reveals About Improving Scores During Online Exams [23]. That is, in 2020 there were higher grades in its average. Which means that students' grades have risen significantly since e-learning was introduced at the beginning of the pandemic. In the results of [24], Through their survey, they detailed that the majority of students in a $56.3 \%$ They assured that the most used and / or known platform is Zoom. Obtaining a result similar to our work as the most used videoconferencing application for this new mode of education. He also added, and we agree, that the solution of practical exercises such as: mathematics; require more than distance learning.

The results obtained in comparison with the author [10] they coincide, as, video conferencing platforms help teachers and students in teaching and learning work.

\section{CONCLUSIONS AND FUture WORK}

In conclusion, regarding the results obtained from the surveys, the vast majority of teachers and students perform at an advanced level in the platforms for the virtual teaching and learning environment. Likewise, teachers have constant and fluid communication with their students during class partitions. However, some teachers still have difficulties at a psychological level due to this new teaching modality. The teachers mentioned that they are in constant training to learn the new digital tools. Students feel comfortable and motivated during their virtual classes.
The contribution of this research work is aimed at the educational environment, making the results known through online learning surveys. The academic community of the University, made up of students, teachers and authorities, benefit from this work.

Further research is expected later, adding the other departments and comparing little-known video conferencing platforms.

\section{REFERENCES}

[1] S. Wang, L. L. Minku, and X. Yao, "Resampling-based ensemble methods for online class imbalance learning," IEEE Transactions on Knowledge and Data Engineering, vol. 27, no. 5, pp. 1356-1368, 2015.

[2] J. Nainggolan, G. Christian, K. Adari, Y. Bandung, K. Mutijarsa, and L. B. Subekti, "Design and implementation of virtual class box 5.0 for distance learning in rural areas," in 2016 8th International Conference on Information Technology and Electrical Engineering (ICITEE), 2016, pp. 1-6.

[3] F. Lu, X. Chen, X. Ma, Z. Liu, and Y. Chen, "The exploration and practice of it solutions for online classes in higher education during covid-19 pandemic," in 2020 International Symposium on Educational Technology (ISET), 2020, pp. 298-302.

[4] C. Marconi, C. Brovetto, I. Mendez, and M. Perera, "Learning through videoconference. research on teaching quality," in 2018 XIII Latin American Conference on Learning Technologies (LACLO), 2018, pp. 37-40.

[5] M. Vladoiu and Z. Constantinescu, "Learning during covid-19 pandemic: Online education community, based on discord," in 2020 19th RoEduNet Conference: Networking in Education and Research (RoEduNet), 2020, pp. 1-6.

[6] C. Diaz-Nunez, G. Sanchez-Cochachin, Y. RicraChauca, and L. Andrade-Arenas, "Impact of mobile applications for a lima university in pandemic," International Journal of Advanced Computer Science and Applications, vol. 12, no. 2, 2021. [Online]. Available: http://dx.doi.org/10.14569/IJACSA.2021.0120294

[7] A. García and E. Vidal, "Mobile-learning experience as support for improving the capabilities of the english area for engineering students," in 2019 International Conference on Virtual Reality and Visualization (ICVRV), 2019, pp. 202-204.

[8] A. F. Azmi, R. Nuravianty, T. I. Nastiti, and D. I. Sensuse, "Using social networking sites for learning experiences by indonesian university students," in 2018 International Conference on Advanced Computer Science and Information Systems (ICACSIS), 2018, pp. 177-182.

[9] Y. Bandung, D. Tanjung, and L. B. Subekti, "Design of mleaming application with videoconference system for higher education," in 2017 6th International Conference on Electrical Engineering and Informatics (ICEEI), 2017, pp. 1-6.

[10] J. Sutterlin, "Learning is social with zoom video conferencing in your classroom," ELearn, vol. 2018, no. 12, Dec. 2018. [Online]. Available: https://doi.org/10.1145/3302261.3236697

[11] E. E. A. Rahim, N. Daud, S. A. A. Kadir, and N. W. Jamil, "Students' perceptions of open and distance learn- 
ing (odl) for theoretical and lab-related subjects," in 2020 IEEE Conference on e-Learning, e-Management and $e$ Services (IC3e), 2020, pp. 29-32.

[12] J. S. César, R. G. Elar, T. E. Jhonathan, T. A. Anthony, V. R. Gary, and A. A. Laberiano, "Analysis of the use of technological tools in the e-learning process," in 2020 IEEE ANDESCON, 2020, pp. 1-6.

[13] Rismayani and Y. J. W. Soetikno, "Using webqual 4.0 for measuring quality of e-learning services during covid19 pandemic," in 2020 8th International Conference on Cyber and IT Service Management (CITSM), 2020, pp. $1-7$.

[14] Y. Maher, S. M. Moussa, and M. E. Khalifa, "Learners on focus: Visualizing analytics through an integrated model for learning analytics in adaptive gamified e-learning," IEEE Access, vol. 8, pp. 197 597-197 616, 2020.

[15] A. Sufyan, D. Nuruddin Hidayat, A. Lubis, U. Kultsum, M. Defianty, and F. Suralaga, "Implementation of elearning during a pandemic: Potentials and challenges," in 2020 8th International Conference on Cyber and IT Service Management (CITSM), 2020, pp. 1-5.

[16] L. Kohnke and B. L. Moorhouse, "Facilitating synchronous online language learning through zoom," RELC Journal, p. 0033688220937235, 2020. [Online]. Available: https://doi.org/10.1177/0033688220937235

[17] R. S. Al-Maroof, S. A. Salloum, A. E. Hassanien, and K. Shaalan, "Fear from covid-19 and technology adoption: the impact of google meet during coronavirus pandemic," Interactive Learning Environments, vol. 0, no. 0, pp. 1-16, 2020. [Online]. Available: https://doi.org/10.1080/10494820.2020.1830121

[18] Y. Tabira and S. Goto, "Impact of international postures on willingness to communicate during international exchanges using skype," in 2017 Portland International Conference on Management of Engineering and Technology (PICMET), 2017, pp. 1-5.
[19] D. Pal and V. Vanijja, "Perceived usability evaluation of microsoft teams as an online learning platform during covid-19 using system usability scale and technology acceptance model in india," Children and Youth Services Review, vol. 119, p. 105535, 2020. [Online]. Available: https://www.sciencedirect.com/science/article/pii/ S0190740920313992

[20] V. Kruglyk, D. Bukreiev, P. Chornyi, E. Kupchak, and A. Sender, "Discord platform as an online learning environment for emergencies," Ukrainian Journal of Educational Studies and Information Technology, vol. 8, no. 2, pp. 13-28, Jun. 2020. [Online]. Available: https://www.uesit.org.ua/index.php/itse/article/view/303

[21] N. Nasrat, A. Khamosh, and K. Lavangnananda, "Challenges and hurdles to e-learning implementation during covid-19 outbreak: A case of shaikh zayed university," in 2020 International Conference on Informatics, Multimedia, Cyber and Information System (ICIMCIS), 2020, pp. 242-246.

[22] Y. Chaiko, N. Kunicina, A. Patlins, and A. Zhiravetska, "Advanced practices: web technologies in the educational process and science," in 2020 IEEE 61th International Scientific Conference on Power and Electrical Engineering of Riga Technical University (RTUCON), 2020, pp. $1-6$.

[23] R. M. Cosnită, A. Maria Cimpean, and M. Raica, "Online versus on-site e-assessment in medical education: are we ready for the change?" in 2020 International Symposium on Electronics and Telecommunications (ISETC), 2020, pp. 1-4.

[24] S. M. Mambo and F. Makatia Omusilibwa, "Effects of coronavirus pandemic spread on science, technology, engineering and mathematics education in higher learning institutions," in 2020 IFEES World Engineering Education Forum - Global Engineering Deans Council (WEEFGEDC), 2020, pp. 1-4. 